\title{
How Uniformity of Tree Distribution Affects Stand Growth
}

\author{
W. M. Stiell ${ }^{1}$
}

\begin{abstract}
Part of a 13-year-old plantation of red pine (Pinus resinosa Ait.) was thinned to leave stems uniformly distributed throughout the stand, and another part was thinned to leave the same number of stems but in equally spaced 4-tree clumps. After 10 years the clumped trees had smaller live crowns (owing to more intense shade on the inside of the clumps), reflected in lower growth in d.b.h. and basal area per hectare, and higher form class. No significant difference between treatments was found in volume per hectare, but it was concluded that 5 -tree or larger clumps would result in reduced wood production.
\end{abstract}

\section{Résumé}

Une coupe d'éclaircie a été pratiquée sur une partie d'une plantation de pin rouge (Pinus resinosa Ait.) âgée de 13 ans, laissant les tiges distribuées de façon uniforme d'un bout à l'autre du peuplement, tandis qu'une autre partie a été éclaircie laissant le même nombre de tiges mais en groupes, également espacés, de 4 arbres. Après 10 années, les cîmes vivantes des arbres en groupes étaient plus petites (à cause de l'ombre plus intense à l'intérieur des groupes) avec une croissance réduite du dhp et de la surface terrière à I'hectare ainsi qu'une classe de forme plus élevée. Aucune différence significative entre les traitements n'a été observée pour ce qui est du volume à l'hectare, mais on estime qu'avec des groupes de 5 arbres ou plus la production en bois serait réduite.

\section{Introduction}

Uniform distribution of stems throughout a forest stand is usually expected to ensure equal growth opportunities and best utilization of the site (Dunning 1923; Baker 1934, p. 395; Toumey and Korstian 1947, p. 448; Bella 1967). These ideas are inherent in planting policies which call for regular spacings, and thinning operations which aim at leaving an evenly stocked stand. Some degree of departure from the perfect model is always found, ranging from occasional irregularities to clumps of trees interspersed with large openings. The question is, how far can the latter type of distribution develop without affecting stand volume growth? The question is worth answering, since efforts at control of distribution represent a cost of stand management, and should therefore be justified.

This paper presents interim results of a thinning experiment designed to compare per tree and per hectare growth of a stand thinned to leave stems equally spaced with growth of a stand thinned to leave the same number of trees, but growing in clumps.

\footnotetext{
1 Research Scientist, Department of Fisheries and Environment, Canadian Forestry Service, Petawawa Forest Experiment Station, Chalk River, Ontario.
}

\section{Design Rationale}

Unequal distribution of stems in a stand implies that some trees have closer neighbours than others, and therefore experience more competition and make slower diameter growth. An extreme example is where two seedlings are planted in the same hole and grow up as twin stems, or "doubles". When the stand closes, the correctly spaced, single trees receive equal competition on each side from their neighbours in the same row and in the two adjoining rows. On the other hand, each stem in a double has the additional and very severe competition from its twin, which results in much shorter live crowns on the inward-facing sides of the two stems. Sometimes naturally established doubles are found which have made good growth. These stems may be otherwise isolated, and have well-developed external crowns. It might be argued from this that as long as a tree's crown has one or more "sides" free, stem growth will not be impeded. This brings us back to the question of whether or not small groups of trees with spaces between them will give as good average diameter growth as equally spaced trees. This is the point at issue since development of a thinned stand means development under conditions of reduced competition, whose spatial disposition can readily be manipulated.

The experiment described here was conducted in a plantation where uniformity of pre-treatment spacing was ensured and it was possible, by cutting, to vary stem distribution while holding numbers of trees per unit area constant. A mechanical thinning was adopted to give equal release to all residual stems in the single-tree thinning and still maintain uniform spacing. In the alternate treatment, where trees were to be left in groups, 4tree clumps were selected as the largest in which all trees would be equally released; in larger clumps one or more trees would receive greater competition than their associates.

\section{Methods and Materials}

The experiment is being conducted on property of Atomic Energy of Canada Limited, near Chalk River, Ontario. The stand is a plantation of red pine (Pinus resinosa Ait.) established at a regular spacing of about $1.68 \mathrm{~m} \times 1.68 \mathrm{~m}$ on a sandy, old field site. In the fall of 1965 , when the thinning was carried out, the stand was 13 years old and averaged about $5.5 \mathrm{~m}$ tall.

Eight 0.04 -ha plots were laid out in the plantation. Four plots, selected at random, were thinned by removing every other row and sufficient stems in the remaining rows to leave 35 or 36 uniformly distributed stems (Figure 1). Average 
number of trees per plot was 35.2, equivalent to a spacing of about $3.35 \mathrm{~m} \times 3.35 \mathrm{~m}$, after this single tree thinning. Plot surrounds were treated in like manner.

The other four plots were subjected to clump thinning. Each of these plots, together with its surround, was thinned to exactly 36 trees, distributed in nine 4-tree clumps equally spaced.

On each plot, after thinning, trees were tagged at breast height and mapped. Total height, and diameter at breast height and at half height above b.h., were measured on every tree. The data were summarized by d.b.h.-classes and a stand table of numbers of trees, basal area and total volume was prepared. Average d.b.h. (quadratic mean) and arithmetic mean height were calculated. Average form class (ratio of diameter at half height above b.h. to d.b.h.) was derived from the d.b.h. class values, weighted by their basal areas. Volumes were estimated by applying a regression (developed previously from taper measurements taken elsewhere in the plantation) to values from Formclass Volume Tables (Anon 1948). Basal areas and volumes per hectare for each 35-tree plot were multiplied by $36 / 35$ to equalize stand density.

After the 1970 and 1975 growing seasons all measurements were repeated, and in addition the height to the first live branch and the height to the first wholly live whorl were determined. Similar compilation procedures were followed.

Mean treatment values for 1965, 1970, and 1975 , and for 5-and 10-year changes, were com- pared by analysis of variance for completely randomized design according to the procedure described by Freese (1967).

\section{Results and Discussion}

Treatment means of measurement and growth data are shown in Figure 2, together with significance of differences as determined by $F$ test.

In 1965, after thinning, neither average tree dimensions nor per hectare values differed significantly between treatments ( $P=0.05$ or less).

Over the next 10 years mean height showed no treatment effect, but by 1975 average d.b.h. was significantly greater for the single-tree thinning. While both treatments experienced form class increases, values were higher for the clumped trees in 1970 and 1975.

These changes were coincident with changes in the crowns. Height to the first live branch was the same in 1970 for both treatments, yet height to the first wholly live whorl was much greater for the clumped trees. This was caused by live branches persisting quite far down the stem on the outside of the clumps where the nearest competitor was, on the average, $5 \mathrm{~m}$ away. On the inside of the clumps, however, the close proximity of competitors shaded out the lower branches (Figure 1). By 1975 height to the lowest branch had increased slightly, but more for the single trees since crowns had closed in that treatment. While height to the first live whorl had increased
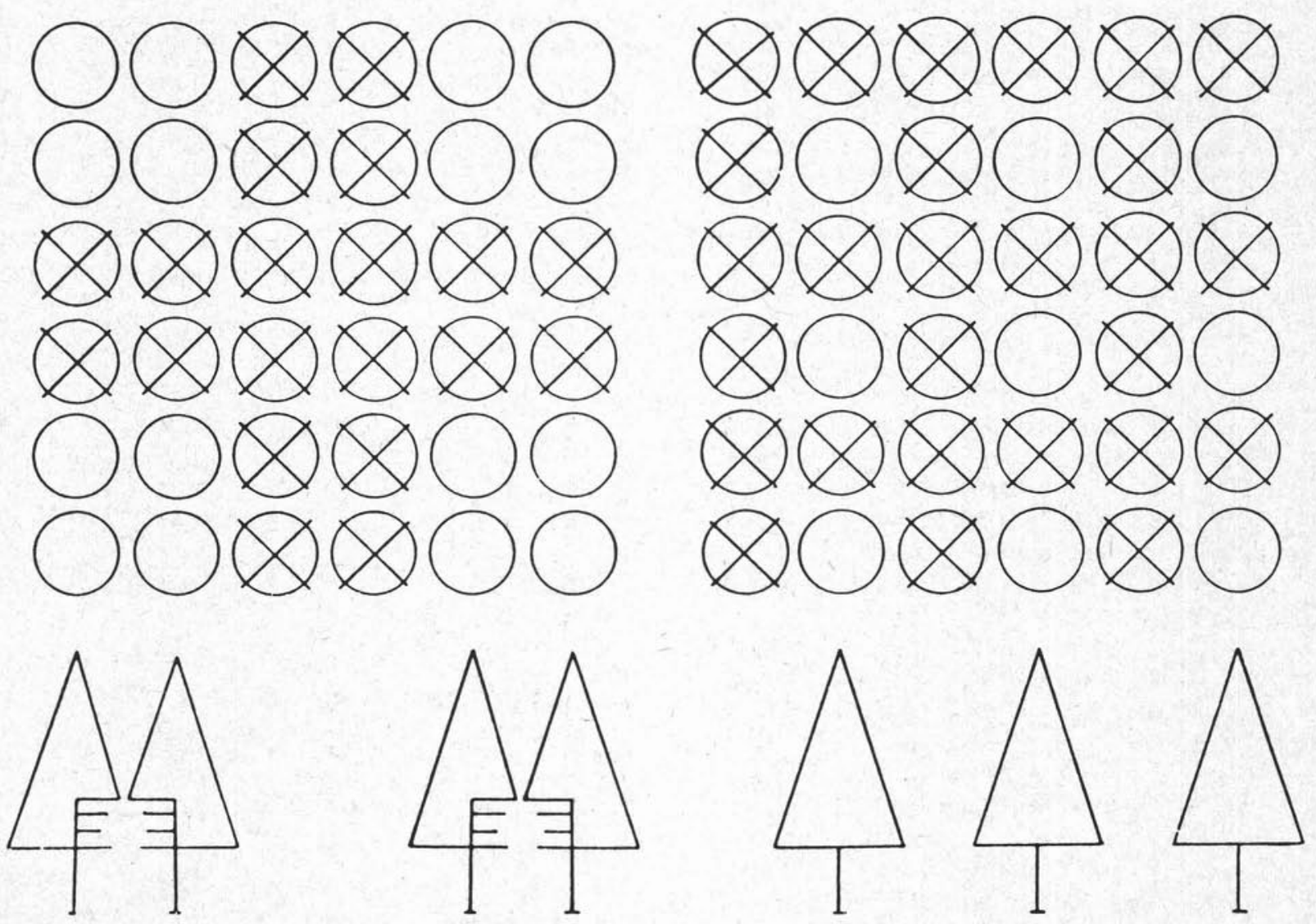

Fig. 1. Thinning pattern for clumps (left) and single trees (right). Circles with " $X$ " indicate thinned trees. Below, schematic diagram of subsequent crown development. 

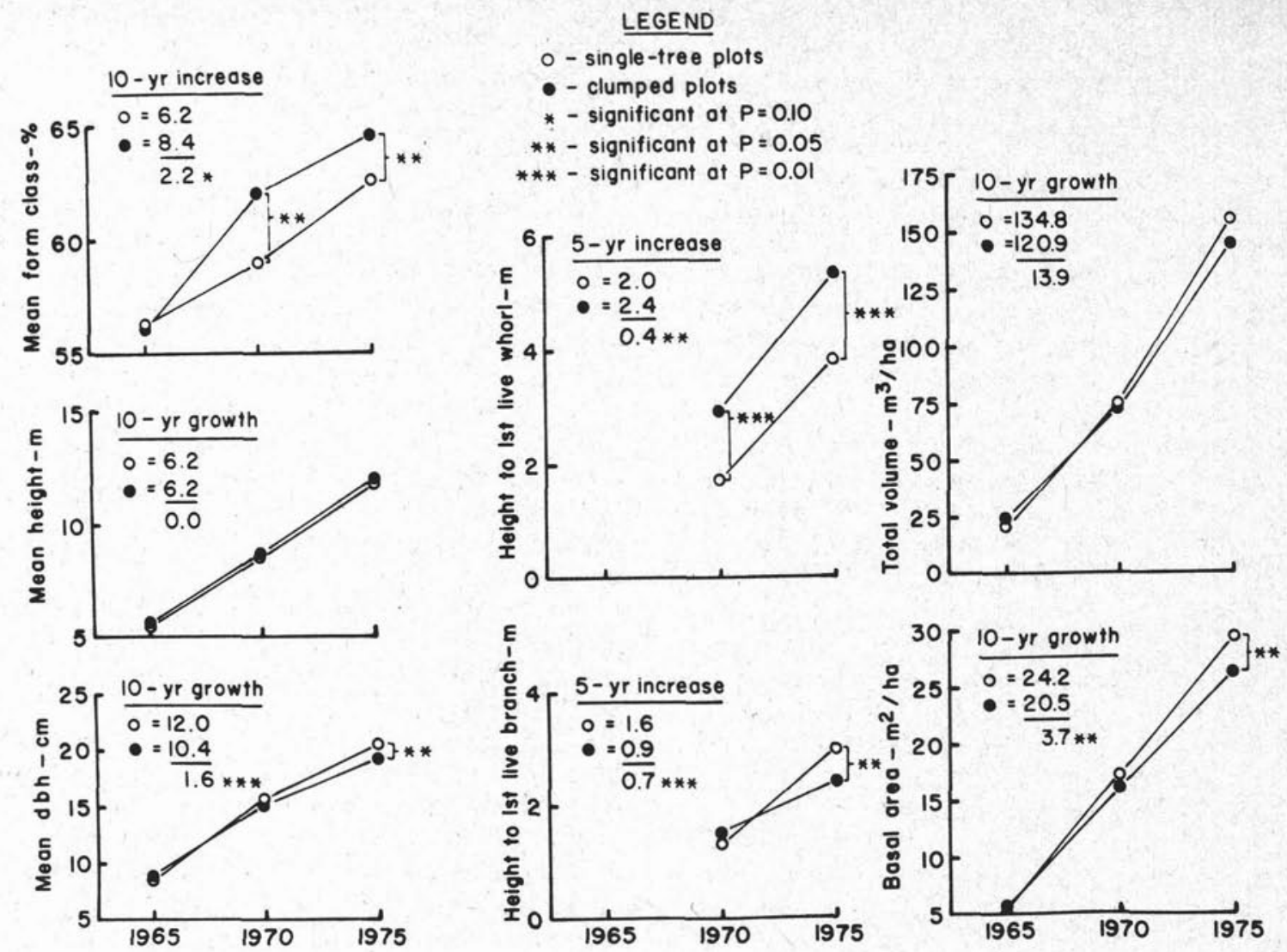

Fig. 2. Mean stand values, by treatment and date.

sharply for the single trees, it was still greater for the clumped thinning treatment.

It is evident that the clumped trees suffered an overall reduction in quantity of foliage, in comparison with the single trees, resulting in lower d.b.h. growth. In terms of per hectare values, then, stand basal area increment was significantly less in the clumped thinning. For cubic content, however, the higher form class of the clumped trees (indicating more cylindrical stems) partially offset their lower basal area, and no significant difference in stand volume could be shown at any date.

Uniformity of spacing, therefore, has resulted in more tapering stems with greater d.b.h., but has not affected total volume. The 1970-75 trends (diverging basal areas, converging form class) suggest that the clumped stands might yet contain the lower volumes, but if so the difference would soon stabilize now ràtes of crown recession are about equal.

It appears that, in these circumstances, clumps of 4 or fewer trees will not seriously reduce wood production, although they can redistribute it along the stem. This seems to be the maximum size of group which spacing control should permit. Larger clumps, i.e. 5 or more trees, would almost cer- tainly cause losses in growth, since some trees would receive very little more growing space after thinning as compared to 4-tree clumps in which each crown was given a $50 \%$ release.

While the necessary degree of spacing control for all situations cannot be inferred from this experiment, nevertheless it indicates that considerable departure from uniform intertree distance can be feasible provided the number of trees per unit area prescribed for the particular operation is maintained.

\section{References}

Anon. 1948. Form-class volume tables. 2nd ed. Can. Dep. Mines Resour., Mines, For. Sci. Serv. Branch, Dom. For. Serv.

Baker, Frederick S. 1934. Theory and practice of silviculture. McGraw-Hill Book Co., Inc., New York and London. 2nd ed.

Bella, I. E. 1967. Development of jack pine and Scots pine in the Spruce Woods Forest Reserve, Manitoba. Can. Dep. For. Rural Dev., For. Branch, Dep. Publ. 1171.

Dunning, D. 1923. Some results of cutting in the Sierra forests of California. U.S. Dep. Agric. Bull. 1176. Cited by Baker 1934, op. cit.

Freese, Frank. 1967. Elementary statistical methods for foresters. U.S. Dep. Agric., For. Serv., Agric. Handb. 317.

Toumey, James W. and Clarence F. Korstian. 1947. Seeding and planting in the practice of forestry. 3rd ed. John Wiley \& Sons, Inc., New York. 